Volume 7 Issue 2, June 2020

Nationally Accredited Journal,

Decree No. B/4130/E5/E5.2.1/2019

\title{
Distribution Of Inheritance To Non Moslems Heirs In Notary Deed From Islamic Inheritance Law Perspective
}

\author{
Andi Hamniza Kastury ${ }^{1}$, Aynun Nurmayanti ${ }^{2}$ and Munsharif Abdul \\ Chalim $^{3}$
}

\begin{abstract}
The aim of this study was to: 1) To determine the position of non-Moslem heirs to the estate heir which has Islamic religion. 2) To identify and analyze how inheritance to heirs of non-Moslems in terms of the deed of Islamic inheritance law.

Based on the data analysis concluded that: 1) The position of non-Moslem heirs of inheritance toward Moslem is not called heirs because of differences in religion, but he is entitled to receive a portion of the deceased's estate by his parents was borrowed.

2) The division of inheritance to heirs of non-Moslems are equal parts by the beneficiaries (women) and the other in the act of notary deed evidence obligatory will be made, each of which must be a testament that the act in order to obtain legal certainty as authentic documents binding.

Keywords: Division of Heritage; Non Moslem Heirs; Notary Deed; Islamic Inheritance Law.
\end{abstract}

\section{Introduction}

Inheritance law is very closely related to the scope of human life in this world. It is basically a man in this world would experience a very important event in his life and is commonly called the law and died. When there is a legal event, the death of a person who consequently lost their sense of their immediate family may be very loved and can lead to legal consequences, namely on how the continuation of the rights and obligations of a person who had died of it. Management solution and the rights and obligations of a person as a result of the events that caused the death of a person shall be governed by the laws of Islam. Namely through the Inheritance Law.

During his life every man has a property. That wealth will be distributed to those who deserve it the closest descendant of the deceased or the person designated to receive it. The man who died was named heir, while entitled to receive the assets of the named beneficiary. ${ }^{4}$ So the inheritance law is a law governing the inheritance of a person who has passed away and given to the beneficiary.

The law of inheritance in Islam gets the most attention because of inheritance often lead to consequences that are unfavorable to the bereaved family. Heritage is a question of what and how the various rights and obligations of one's wealth when he die will switch to the surviving family. ${ }^{5}$ It shows the importance of the issue of inheritance. Islamic inheritance law basically applies to Moslems anywhere in the

\footnotetext{
${ }^{1}$ Students of Master of Notary Program, Faculty of Law, Sultan Agung Islamic University (UNISSULA), Semarang, email: andihamnizakastury@gmail.com

${ }^{2}$ Student of Master of Law Program, Faculty of Law, Universitas Islam Sultan Agung email aynunnurmayanti@gmail.com

${ }^{3}$ Lecturer of Master of Law, Sultan Agung Islamic University (UNISSULA), Semarang

${ }^{4}$ Sudarsono, 1992, Pokok-pokok Hukum Islam, ed. I , PT. Rineka Cipta, Jakarta, p.288

5 Ahmad Rofiq, 1998, Hukum Islam di Indonesia, 3rd edition, PT. Raja Grafindo Persada, Jakarta, p. 356.
} 
world. The basis of everything is the ultimate Islamic inheritance laws that have been established in the Qur'an and Sunnah then applied in the community such as the rule of Islamic Law Compilation. In Islam stated on the inheritance and the people who deserve it.

For example in the history Ibn Majah and Addaruqutni said that the Prophet Muhammad said:

"Learn Fara'idh and teach it to the people, because inheritance is half science and knowledge is easily forgotten and lost for the first time of my ummah."

In a hadith narrated by Ahmad ibn Hanbal said:

Learn the Qur'an and teach it to the people; Fara'idh also learn and teach it to the people; because I was the man who at one point scientist die and be lost; almostalmost two disputants in Fara'idh and the thing is, they did not find the man who told how the solutions.

It can be seen from the above reasoning, it is becoming clear that inheritance law is vital to be known and studied by people who recognize Islam.

One of the debate concerning the succession of thinkers recent is associated with inheritance rights of non-Moslems. As it is known that the treasures of classical figh mentioned that in one of the causes of interruption of the inheritance rights of a person when the person is in a state of non-Moslems and apostates or in condition (converted from Islam to non-Moslems). Religious differences between heir and heir is a breakdown in terms of inheritance rights of a person. This law is getting a suit of contemporary thinkers because they are contrary to the universal values of Islam, justice and human rights.

Therefore, thinking about inheritance until now has not stopped, although it is known that Islam has set in due time ago. In this context, the scholars have agreed to make the science of inheritance which was then called Fara'idh as a stand-alone branch of science $^{6}$. Even the teachings of Islam learn about the heritage of Islam, also known as Fara'idh get a special appeal.

Based on the background mentioned above, the authors are interested in doing further research to be formulated in the form of a study entitled: "Distribution Of Inheritance To Non Moslems Heirs In Notary Deed From Islamic Inheritance Law Perspective". With the problems: 1 . How the position of non-Moslem heirs to the estate heir in Islamic religion. 2. How inheritance to non-Moslems heirs in terms of Notary Deed of Islamic Inheritance Law.

\section{Research Methods}

The method used in this research is normative. The specifications used in this study is normative. Data in the study consisted of primary legal materials, secondary and tertiary. The method of data analysis done for normative interpretation or interpretation of the law were given argument is a conclusion on the issues discussed.

\section{Results and Discussion}

\subsection{Non-Moslem Heirs position in Islamic Inheritance of Moslem}

\footnotetext{
${ }^{6}$ Ahmad Azhar Bashir, 1999, Hukum Waris Islam, Economics Ekonosia UII, Yogyakarta, p.7
} 
Volume 7 Issue 2, June 2020

Nationally Accredited Journal,

Decree No. B/4130/E5/E5.2.1/2019

Inheritance rights of a person shall not appear suddenly but its existence is constituted by some reason the function switch of the rights of the deceased. Beneficiaries are individuals whose where abouts have been determined the texts of both the Qur'an and the Hadith.

Religious differences are a barrier that can drop the inheritance rights of a person's heirs. In other words, the barriers to inherit an action or things that can drop a person's right to heirs after their causes to inherit. ${ }^{7}$

According to the hadith of the Prophet Muhammad, which means: "It is not right to inherit a Moslem infidels, nor inherit the Moslem infidels." (HR. Bukhari and Moslem).

But the Supreme Court's decision No.368.K / AG / 1995, dated June 16, 1998. Yang said: "The biological child (women) who are non-Moslems (Christians) are not the heirs of their legal status, but it is entitled to a share of property inherited by both parents deceased "was borrowed" a part similar to the child (female) beneficiaries of the deceased father and mother ". 8

Supreme Court seems to be different than the norm, which is contained in the Quran, the Sunnah of the Prophet and the Islamic Law Compilation. In the life of a well compound it is possible in a family made up of family members of different religions. To satisfy the sense of justice as one of the principles of Islamic inheritance law, the non-Moslems in fact entitled to part of the inheritance with the construction of the will, or "obligatory will" when the deceased did not make a will for them. The construction will be aimed at alternative ways complementary solution for those beneficiaries who do not obtain the inheritance, but has a close relationship with the heir.

\subsection{To Know And Analyze How Inheritance To Non-Moslems Heirs In Terms Of The Notary Deed In Islamic Inheritance Law}

Notary as a public official authorized by law to make the deed. In the case of inheritance reserved for non-Moslem heirs, then administered through obligatory will, as has been described in previous chapters. This is reinforced by the opinions of the scholars Shafi'iyah, Hanafiyah, and Hanbali allows bequeath to non-Moslems, provided that given the will not fight Moslems. This they qiaskan to the problem hibbah and charity set forth in the Quran, Surah Mumtahinah [60]: 8, which means: "Allah does not forbid you to do good and be fair to those who do not fight you because of religion nor drove you out of your land, Indeed, Allah loves those who act justly. ${ }^{9}$

In relation to the obligatory will to the heirs of non-Moslems, then as a notary public office as may be authorized by UUJN have a role in making the evidence obligatory will act, where every testament it is to be shaped in order to obtain legal certainty act as authentic documents binding. Judging from its manufacture by a notary, the heir testamentary bequest evidence can be classified into: ${ }^{10}$

\footnotetext{
${ }^{7}$ Rafiq Ahmad, Fiqh Mawaris, PT. King Grafindo Persada, Jakarta, p.16

${ }^{8}$ Ahmad Khisni, Hukum Waris Islam, Second Printed, Unissula Press, Semarang, p.50

9 James Diah Kusuma, Role Notary / PPAT In Manufacturing Distribution Act Against Heirs Inheritance Different Religious Organizations Act Vol 5 No 1 March 2018, http://jurnal.unissula.ac.id/index.php/akta/article/view/2537 Accessible on Friday December 6, 22:00 pm

${ }^{10}$ GHS Lumban Tobing, Peraturan Jabatan Notaris, Erlangga, Jakarta, p. 51-52
} 
- Announcement Act, acts committed by officials that the manufacturing notary, or;

- Partij deed, deed of which construction is carried out in the presence of a notary.

Next on the execution was borrowed for non-Moslem heirs, by a notary public in addition to listening to the purpose of the party attended, notaries are also considered necessary to ask some questions to elicit information regarding previous made deed, as well as original equipment requested document to be presented at the notary. While some documents on which these requirements include:

- Death Act heir

- Identity Card heir receiver

- Letter or other supporting documents which prove the recipient is a true heir is a child of the testator, and can be justified in writing and / or orally at the time was facing a notary by a sibling of the recipient non-Moslem heirs testamentary bequest.

- Act or testament, if the letter is stated that the testator left a will.

After requirements / documents that have to be checked for their legality, as well as listening to the evidence for the repairing, it is also necessary to make a statement on the validity of the documents and the evidence for the repairing can be made by deed or deed under the hand and the statement will be attached to the minutes of the Act. Then pour the evidence act heir testamentary bequest in the form of minutes of the Act. Then the notary will read the Evidence Act beneficiaries attended and in front of witnesses. Furthermore, the last section of the Evidence Act, signed by the party attended the heirs and witnesses and the notary.

Reading activities in front of the Evidence Act Inheritance attended and witnesses basically, this activity is meant for the attentio and witnesses know the content of the act. Usually, the notary read out the contents of the Evidence Act inherit directly in front of the party attended and witnesses.

Only Notary Act regulates other technical substitute for direct readout and must be explicitly stated in the deed. So, in the case of execution was borrowed for nonMoslem heirs, the notary has a role in providing services making authentic documents as mandated by UUJN.

The heir to the evidence act in it describes the gift in a will bequest. So for nonMoslem heirs by beneficiary deed is evidence can provide legal certainty and have perfect verification strength, good physical strength of evidence (uitwendige bewijsracht), the power of formal proof (formele bewijsracht) and the strength of evidence material (materiele bewijsracht) ${ }^{11}$, Thus the non-Moslem heirs have the legitimacy in obtaining parts

\section{Closing}

\subsection{Conclusion}

Based on the research results can be concluded as follows:

- The position of non-Moslem heirs of inheritance toward Moslem is no longer called the heir because of differences in religion, that which has been said in the Qur-an is QS. An-Nisa '(4) verse 141: "And God never gives a way for the infidels (the master of the believers)". Similarly in verse. Al-Maidah (5), paragraph 48: "To each

\footnotetext{
${ }^{11}$ Nugraheni, Ilhami \& Harahap, setting and implementation of obligatory will, Pulpit Law, Vol. 22, No. 2, June 2010, p. 316
} 
Volume 7 Issue 2, June 2020

Nationally Accredited Journal,

Decree No. B/4130/E5/E5.2.1/2019

among you, We have rules and procedures (individually). The legal basis for the compilation of Islamic law that religious differences is one of the barriers a person to be a beneficiary, specified in Article 171 of Chaos (c), but the Supreme Court's ruling that the case is that it is entitled to part of the estate of the deceased parents by the will bequest, with basic considerations of fairness and also refers to the problems hibbah and charity set forth in the Quran Mumtahinah [60]: 8, which means: "Allah does not forbid you to do good and be fair to those who do not fight you because of religion and did not drive out you from your homes. Indeed, Allah loves those who act justly.

- Inheritance to heirs of non-Moslems is not through inheritance but through obligatory will. Obligatory will is a will that is allocated to the heirs or relatives who do not obtain the inheritance of a person who died due to an obstruction of Personality. Clay in his Mainheritance Figh (Islamic Inheritance Law), as obligatory will define the implementation of which will not be affected or not depends on the will or the will of the deceased. And a large part of the investment is equal to a daughter, not $1 / 3$ of the estate and it is not part of the acquisition $3 / 4$ daughter and heir of the notary deed made obligatory will Evidence Act,

\subsection{Suggestions}

- The position of non-Moslem heirs toward estate heir who said Moslems no longer as beneficiaries but still get their rights by way of bequest is highly accurate results and is very fair. That where each party has the right to get better, because Islam also teaches kindness and justice in the lives of fellow human beings as well.

- Inheritance for heirs of non-Moslems was already very fair, but the lack of clarity regarding the form and content of the standard explanations of the evidence obligatory will in the act of the beneficiary. In the case of the notaries interpret itself with individual capacities of notaries and poured it into the act, to the extent not in conflict with the law. So with so necessary to the seminar and forum for public dialogue devoted to the making of systematic evidence for obligatory will own inheritance.

\section{References}

[1] Bashir Ahmad Azhar, 1999, Hukum Inheritance Islam, Economics Ekonosia UII, Yogyakarta.

[2] Ahmad Khisni, Hukum Inheritance Islam, Print. $2^{\text {nd }}$, Unissula Press, Semarang.

[3] Ahmad Rofiq, 1998, Hukum Islam di Indonesia, Print. $3^{\text {rd }}$, PT. King Grafindo Persada, Jakarta.

[4] --------- 2002, Fiqh Mainheritance, Print. 4 ${ }^{\text {th }}$, PT. King Grafindo Persada, Jakarta.

[5] GHS Lumban Tobing, 1999, Peraturan Jabatan Notaris, Erlangga, Jakarta.

[6] Nugraheni, Inspire \& Harahap, 2010, Pengaturan dan Implementasi Wasiat Wajibah, Mimbar Hukum, Pulpit Law, Vol. 22, No. 2.

[7] Soerjono Ancol and Sri Mamudji, 2001, Penelitian Hukum Normatif (Suatu Tinjauan Singkat), Rajawali Press, Jakarta.

[8] Sudarsono, 1992, Pokok-pokok Hukum Islam, ed. I, PT. Rineka Cipta, Jakarta. 


\section{JURNAL AKTA}

Volume 7 Issue 2, June $2020: 209-214$

eISSN : 2581-2114, pISSN: 2406-9426

[9] Compilation of Islamic Law

[10] http://jurnal.unissula.ac.id/index.php/akta/article/view/2537 Accessible on Friday December 6, 22:00 pm

[11] http://akhmeeed.blogspot.com/2016/11/pengertian-wasiat-wajibah-dalam-khidan.html accessed on 23 December at $09.00 \mathrm{pm}$ 